\title{
Performance and Genotypic Variability of Three Bread Wheat Cultivars under Stress Irrigation Regimes
}

\author{
I.S. El-Degwy \\ Agronomy Department, Faculty of Agriculture, Kafrelsheikh \\ University, Kafrelsheikh, Egypt.
}

\begin{abstract}
7 WO FIELD experiments were conducted at the experimental farm of Faculty of Agriculture, Kafrelsheikh University, Egypt during 2011/2012 and 2012/2013 seasons. The main objective of this investigation was to study the influence of three levels of drought stress imposed during critical stages on the performance and genotypic variability of three bread wheat cultivars. Results indicated that exposure wheat plants to moderate (two irrigations) or high stress (only one irrigation) decreased significantly all characters (except spike length) compared with low drought stress (three irrigations). However, the differences between moderate and high drought stress were not significant for No. of spikelets/ spike and No. of grains/ spike. Large variations among wheat cultivars were recorded for all the studied characters, indicating that wide range of genetic variability were present among the studied cultivars. As average over stress regimes, Sids 12 recorded the most desirable values for spike length, No. of spikelets/ spike, No. of grains/ spike, spike weight and grain yield. Whereas, the differences between Sids 12 and Misr 1 were not significant for grain yield. Misr 1 gave the highest values of plant height, heading date, No. of spikes/ $\mathrm{m}^{2}$ and 1000-grain weight. Heading date, plant height, spikes/ $\mathrm{m}^{2}, 1000$-grain weight and grain yield were significantly affected by the interaction between irrigation regimes and wheat cultivars. The highest grain yield was recorded for both Misr 1 and Sids 12 wheat cultivars under low irrigation stress (0.62 and $0.59 \mathrm{~kg} / \mathrm{m}^{2}$, respectively). However, the differences between moderate and high stress were not significant (for grain yield) in case of Giza 168. Correlation analysis of yield and yield related characters indicated that under low drought stress condition, No of spikes $/ \mathrm{m}^{2}$ and 1000 -grain weight was positively correlated with grain yield. While, these traits were spike length, No. of spikelets/ spike, No. of grains/ spike and spike weight in case high drought stress conditions. The extent of coefficient of variation indicated that high estimates of phenotypic (PCV) and genotypic (GCV) coefficients of variability were exhibited by number of grains/ spike (23.7 and 22.3), number of spikes/ $\mathrm{m}^{2}$ (26.1 and 24.14), spike weight (26.5 and 24.2) for PCV and GCV, respectively.
\end{abstract}

Keywords: Wheat cultivars, Drought stress, Genotypic variability, Correlation.

Correspondence e- mail: iseldegwy@yahoo.com 
Wheat (Triticum aestivum L.) is the most important and most widely cultivated cereal crop worldwide. Great efforts are continuously executed to increase its productivity. Drought stress is one of the major constrains that affects yield productivity and consider a major restriction to agricultural production in arid and semi arid region. The reduction in grain yield depends upon the growth stage at which the moisture stress occurs as well as the severity and duration of the deficiency. The sensitive growth stages of wheat to water stress were from stem elongation to booting, followed by anthesis and grain filling (Zhang \& Oweis, 1999). Shortage of irrigation water during vegetative stage can markedly affect spike development and decrease yields of cereal grains (Blum et al., 1991). Subjecting wheat cultivars to moderate or severe water stress at any of these stages; seeding to maximum tillering, maximum tillering to flowering or at flowering to maturity decreased plant height, ear number, 1000-grain weight and grain yield (Choudhury \& Kumar, 1980). Water stress during vegetative and reproductive development is equally injurious to wheat and adequate water supply throughout crop development is essential to harvest maximum biological potential (Qadir et al., 1999). Skipping one irrigation at heading date decreased all the studied traits including grain yield and yield related traits (Sharaan et al., 2000). Plant height, productive tillers/ plant, spikelets/ spike, spike length, grains per spike, 1000-grain weight and grain yield reduced at less moisture conditions (one irrigation) while sterility percentage was increased (Ali \& Akhter, 2008). Exposure of plants to drought stress under high temperature significantly decreased number of ears/ plot, mean weight of seed per spikelet and grains/ ear (Amin, 2011).

Knowledge about inheritance and genetic control of different traits is important for plant breeders. Changes in environments cause changes in genetic architect of characters (Chowdhry et al., 1999). Genotype $\mathrm{x}$ environment interaction is the main reason for these changes especially accrued in stress conditions (Sharma et al., 2002). Phenotypic correlation under normal conditions was studied by many researchers while, the relation under water stress have limited investigations. Under drought stress conditions, ear number per square had the highest correlation with grain yield, whereas these traits were grains number per ear for the well watered conditions (Eman et al., 2012). Grain yield was positively correlated with each of plant height, spike length, grains/ spike and 1000-grain weight under water stress condition and with tillers/ plant, spike length, grains/ spike and 1000-grain weight plant under irrigated conditions condition (Subhani \& Chowdhry, 2000). Spike length was positively correlated with spikelets/ spike and grain yield and negatively with 1000-grain weight (Khan et al., 2005).

This investigation was conducted to study the influence of three levels of drought stress imposed during critical stages on the performance and genotypic variability of three bread wheat cultivars. 


\section{Materials and Methods}

The present study was conducted in the experimental farm of Faculty of Agriculture, Kafrelsheikh University, Egypt, during 2011/2012 and 2012/2013 seasons. The experimental materials comprised of three bread wheat cultivars with wide range of morphological and agronomical traits; Sids 12, Misr 1 and Giza 168. All cultivars were grown under three stress irrigation regimes; T1-Low water stress, having three irrigations; the first at crown root initiation, the second at heading and the third at grain filling, T2-moderate irrigation stress (two irrigations) one at crown root initiation and the second at heading and T3-high stress (only one irrigation) at crown root initiation. A randomized complete block design with three replications was employed for each irrigation regime. The experimental plot was $10.5 \mathrm{~m}^{2}(3 \times 3.5 \mathrm{~m})$. Wheat cultivars were sown by broadcasting on the third week of November in both seasons. The type of the soil was clay, and the scientific name according to FAO is Typic Torrifluvent (Soil Survey Staff., 2010). To avoid the effect of lateral movement of flooding water, each treatment was isolated by ditches. Recommended practices of fertilization and weed control were applied.

Data were recorded on plant height, heading date, spike length, No. of spikelets/ spike, No. of grains/ spike, No. of spikes/ $\mathrm{m}^{2}$, spike weight, 1000-grain weight and grain yield. Analysis of variance was conducted according for each season according to Steel \& Torrie (1980). Error variances from separate analysis of the data were tested for homogeneity using Bartlett (1937). As such error was homogenous, the combined analysis was calculated for the data of the data of the two seasons according to Gomez \& Gomez (1984). Phenotypic (PCV) and genotypic (GCV) coefficients of variability were estimated according to Burton (1952). The expected genetic advance from selection as reported by Johanson et al. (1955). Broad sense heritability over water stress treatments was calculated following Singh \& Chaudhary (1985).

Drought susceptibility index (DSI) was calculated according to the formula given by Ali et al. (1990) as follows: DSI= NS-S/ NS.

where: NS: is yield under normal conditions, $S$ : is yield under drought conditions.

In this study NS and S mentioned to grain yield under three and one irrigations, respectively.

\section{Weather data}

The information about the weather during the growth period of the two seasons is presented in Table 1. Noteworthy, rainfall/rain was calculating by summation the amounts of rainfall over the month in $\mathrm{mm}$ then it divided on the number of rainy days of the month. 
TABLE 1. Monthly average of maximum (day) and minimum (night) air temperature (C), relative humidity (R.H. \%), pan evaporation and amount of rainfall during the growth period of the two seasons.

\begin{tabular}{|c|c|c|c|c|c|c|c|c|c|}
\hline \multirow[b]{2}{*}{ season } & \multirow[b]{2}{*}{ Month } & \multicolumn{3}{|c|}{ Air temperature (C) } & \multicolumn{3}{|c|}{ Relative humidity (\%) } & \multirow[b]{2}{*}{$\begin{array}{c}\text { Pan Evap } \\
(\mathrm{mm})\end{array}$} & \multirow[b]{2}{*}{$\begin{array}{c}\text { Rain fall } \\
(\mathrm{mm} / \text { rain })\end{array}$} \\
\hline & & Max. & Min. & Average & $\begin{array}{l}7: 30 \\
\text { AM }\end{array}$ & $\begin{array}{c}\text { 13:30 } \\
\text { PM }\end{array}$ & Average & & \\
\hline \multirow{7}{*}{$2011 / 12$} & Nov. & 24 & 10.5 & 17.3 & 86.7 & 53 & 69.9 & 0.22 & -- \\
\hline & Dec. & 20.2 & 6.4 & 13.3 & 86.0 & 61.1 & 73.6 & 0.18 & 3.65 \\
\hline & Jan. & 18.2 & 8.4 & 13.3 & 77.5 & 60.3 & 68.9 & 0.21 & 4.88 \\
\hline & Feb. & 17.5 & 9.6 & 13.6 & 75.6 & 62.1 & 68.8 & 0.30 & 2.94 \\
\hline & Mar. & 20.5 & 12.3 & 16.4 & 77.1 & 59.8 & 68.5 & 0.45 & 6.71 \\
\hline & April & 27.1 & 17.1 & 22.1 & 73.5 & 53.5 & 63.5 & 0.52 & -- \\
\hline & May & 30.8 & 20.8 & 25.8 & 75.7 & 50.1 & 62.9 & 0.57 & -- \\
\hline \multirow{7}{*}{$2012 / 13$} & Nov. & 25.3 & 15.5 & 20.4 & 89.2 & 61.8 & 75.5 & 0.19 & 4.44 \\
\hline & Dec. & 21.4 & 10.11 & 15.8 & 84.8 & 60.8 & 72.8 & 0.23 & 2.72 \\
\hline & Jan. & 19.2 & 7.6 & 13.4 & 90.9 & 65.4 & 78.2 & 0.20 & 9.86 \\
\hline & Feb. & 20.8 & 9.0 & 14.9 & 90.2 & 63.9 & 77.1 & 0.29 & 6.86 \\
\hline & Mar. & 24.4 & 12.4 & 18.4 & 79.6 & 50.9 & 65.3 & 0.44 & 9.52 \\
\hline & April & 26.0 & 15.9 & 21.0 & 74.2 & 43.9 & 59.1 & 0.50 & 6.46 \\
\hline & May & 31.4 & 21.8 & 26.6 & 75.0 & 45.8 & 60.4 & 0.61 & -- \\
\hline
\end{tabular}

Source: Sakha Weather Station, Sakha Experimental Station, ARC, Kafrelsheikh, Egypt.

\section{Results and Discussion}

\section{Mean performance}

The performance of irrigation treatments and wheat cultivars for all the studied characters in both seasons and the combined are presented in Tables 2-4. Significant differences among irrigation treatments were detected for all the studied characters in the two seasons and the combined except spike length. Increasing the moisture conditions were associated by delaying heading date, increasing plant height in both seasons and the combined. Under severe water stress (only one irrigation at crown root initiation) wheat plants headed earlier by about six days than higher moisture conditions (Table 2). Sids 12 wheat cultivar was earlier than the two other cultivars and headed after about 96 days from seeding. Holding two irrigations decreased plant height from 105 to $94 \mathrm{~cm}$ as a combined data. Misr 1 wheat cultivar recorded significantly taller plants than the other cultivars in both seasons and the combined; 100.7, 105.1 and 102.9, respectively.

Subjecting wheat plants to moderate or severe moisture stress revealed insignificant effects on spike length in both two seasons (Table 2). Such result indicating that spike length may be more genotypically controlled. Previous results showed that spike length was in-significantly affected by drought stress (Ismail et al., 2003). Sids 12 wheat cultivar recorded the most desirable spike length compared with Misr 1 and Giza 168. Subjecting wheat plants to high moisture stress (one irrigation) reduced significantly plant height and spike length compared with two or three irrigations. similar results were reported by Ali \& Akhter (2008).

Egypt. J. Agron. 35, No. 2 (2013) 
PERFORMANCE AND GENOTYPIC VARIABILITY OF THREE BREAD ... 215

TABLE 2. Means of heading date, plant height and spike length as influenced by water stress and wheat cultivar.

\begin{tabular}{|c|c|c|c|c|c|c|c|c|c|c|}
\hline \multirow{2}{*}{\multicolumn{2}{|c|}{ Variable }} & \multicolumn{3}{|c|}{ Heading date (day) } & \multicolumn{3}{|c|}{ Plant height (cm) } & \multicolumn{3}{|c|}{ Spike length (cm) } \\
\hline & & 2011/12 & $2012 / 13$ & Comb. & 2011/12 & $2012 / 13$ & Comb. & 2011/12 & 2012/13 & Comb. \\
\hline \multirow{4}{*}{$\begin{array}{l}\text { Water } \\
\text { stress } \\
(\mathrm{T})\end{array}$} & Low & $103.4 \mathrm{a}$ & $101.0 \mathrm{a}$ & $102.2 \mathrm{a}$ & $102.5 \mathrm{a}$ & $107.5 \mathrm{a}$ & $105.0 \mathrm{a}$ & 11.5 & 12.8 & 12.1 \\
\hline & Moderate & $100.2 \mathrm{~b}$ & $96.6 \mathrm{~b}$ & $98.4 \mathrm{~b}$ & $95.6 \mathrm{~b}$ & $99.3 \mathrm{~b}$ & $97.5 \mathrm{~b}$ & 12.0 & 11.6 & 11.8 \\
\hline & High & $97.8 \mathrm{c}$ & $95.4 \mathrm{c}$ & $96.6 \mathrm{c}$ & $92.5 \mathrm{c}$ & $95.5 \mathrm{c}$ & $94.0 \mathrm{c}$ & 11.3 & 11.8 & 11.5 \\
\hline & F. Test & $* *$ & $* *$ & $* *$ & $* *$ & $* *$ & $* *$ & ns & $\mathrm{ns}$ & $\mathrm{ns}$ \\
\hline \multirow{4}{*}{$\begin{array}{l}\text { Cultivars } \\
\text { (V) }\end{array}$} & Sids 12 & $97.4 \mathrm{c}$ & $94.7 \mathrm{c}$ & $96.2 \mathrm{c}$ & $98.1 \mathrm{~b}$ & $94.5 \mathrm{~b}$ & $96.3 \mathrm{~b}$ & $12.8 \mathrm{a}$ & $12.3 \mathrm{a}$ & $12.6 \mathrm{a}$ \\
\hline & Misr 1 & $103.2 \mathrm{a}$ & $100.9 \mathrm{a}$ & $102.1 \mathrm{a}$ & $100.7 \mathrm{a}$ & $105.1 \mathrm{a}$ & $102.9 \mathrm{a}$ & $10.7 \mathrm{c}$ & $11.3 \mathrm{~b}$ & $11.0 \mathrm{c}$ \\
\hline & Giza 168 & $99.6 \mathrm{~b}$ & $98.4 \mathrm{~b}$ & $99.0 \mathrm{~b}$ & $95.9 \mathrm{~b}$ & $98.7 \mathrm{~b}$ & $97.3 b$ & $11.6 \mathrm{~b}$ & $12.1 \mathrm{ab}$ & $11.8 \mathrm{~b}$ \\
\hline & F. Test & $* *$ & $* *$ & $* *$ & $*$ & $* *$ & $* *$ & $* *$ & $*$ & $* *$ \\
\hline Interaction & $\mathrm{T} \times \mathrm{V}$ & $*$ & $* *$ & $*$ & $*$ & $* *$ & $* *$ & ns & $\mathrm{ns}$ & ns \\
\hline
\end{tabular}

$*$, ** and ns: Significant at 0.05 and 0.01 levels of probability and not significant, respectively.

Means followed a common letter are not significantly differed at 0.05 level.

TABLE 3. Means of No. of spikelets/ spike, No. of grains/ spike and No. of spikes/ $\mathbf{m}^{2}$ as influenced by water stress and wheat cultivars.

\begin{tabular}{|c|c|c|c|c|c|c|c|c|c|c|}
\hline \multirow{2}{*}{\multicolumn{2}{|c|}{ Variable }} & \multicolumn{3}{|c|}{ No. of spikelets/spike } & \multicolumn{3}{|c|}{ No. of grains/ spike } & \multicolumn{3}{|c|}{ No. of spikes/ $\mathbf{m}^{2}$} \\
\hline & & 2011/12 & $2012 / 13$ & Comb. & 2011/12 & $2012 / 13$ & Comb. & $2011 / 12$ & $2012 / 13$ & Comb. \\
\hline \multirow{4}{*}{$\begin{array}{l}\text { Water } \\
\text { stress } \\
(\mathrm{T})\end{array}$} & Low & $19.9 \mathrm{a}$ & $21.8 \mathrm{a}$ & $20.9 \mathrm{a}$ & $65.6 \mathrm{a}$ & $71.4 \mathrm{a}$ & $68.5 \mathrm{a}$ & $252.7 \mathrm{a}$ & $276.8 \mathrm{a}$ & $264.8 \mathrm{a}$ \\
\hline & Moderate & $19.2 \mathrm{a}$ & $20.6 \mathrm{a}$ & $19.9 \mathrm{~b}$ & $62.1 \mathrm{~b}$ & $66.0 \mathrm{~b}$ & $64.1 \mathrm{~b}$ & $230.3 b$ & $241.9 \mathrm{~b}$ & $236.1 \mathrm{~b}$ \\
\hline & High & $17.9 \mathrm{~b}$ & $19.3 \mathrm{~b}$ & $18.6 \mathrm{c}$ & $59.4 \mathrm{~b}$ & $62.2 \mathrm{~b}$ & $60.8 \mathrm{~b}$ & $216.4 b$ & $228.8 \mathrm{~b}$ & $222.6 \mathrm{~b}$ \\
\hline & F. Test & $* *$ & $* *$ & $* *$ & $*$ & $*$ & $*$ & $* *$ & $* *$ & $* *$ \\
\hline \multirow{4}{*}{$\begin{array}{l}\text { Cultivars } \\
\text { (V) }\end{array}$} & Sids 12 & $20.1 \mathrm{a}$ & $21.9 \mathrm{a}$ & $21.0 \mathrm{a}$ & $86.4 \mathrm{a}$ & $75.6 \mathrm{a}$ & $81.0 \mathrm{a}$ & $195.6 \mathrm{c}$ & $183.0 \mathrm{c}$ & $189.3 \mathrm{c}$ \\
\hline & Misr 1 & $18.1 \mathrm{~b}$ & $19.2 \mathrm{c}$ & $18.7 \mathrm{c}$ & $50.3 \mathrm{~b}$ & $58.5 \mathrm{~b}$ & $54.4 \mathrm{~b}$ & $287.4 \mathrm{a}$ & $326.0 \mathrm{a}$ & $306.7 \mathrm{a}$ \\
\hline & Giza 168 & $18.8 \mathrm{~b}$ & $20.6 \mathrm{~b}$ & $19.7 \mathrm{~b}$ & $56.5 \mathrm{~b}$ & $59.5 b$ & $58.0 \mathrm{~b}$ & $231.4 \mathrm{~b}$ & $223.5 \mathrm{~b}$ & $227.4 \mathrm{~b}$ \\
\hline & F. Test & $* *$ & $* *$ & $* *$ & $* *$ & $* *$ & $* *$ & $* *$ & $* *$ & $* *$ \\
\hline Interaction & $\mathrm{T} \times \mathrm{V}$ & ns & ns & ns & ns & ns & ns & $* *$ & ns & $* *$ \\
\hline
\end{tabular}

*, ** and ns: Significant at 0.05 and 0.01 levels of probability and not significant, respectively.

Means followed a common letter are not significantly differed at 0.05 level. 
TABLE 4. Means of spike weight, 1000-grain weight and grain yield as well drought susceptibility index (DSI) as influenced by water stress and wheat cultivars.

\begin{tabular}{|c|c|c|c|c|c|c|c|c|c|c|c|}
\hline \multirow{2}{*}{\multicolumn{2}{|c|}{ Variable }} & \multicolumn{3}{|c|}{ Spike weight (g) } & \multicolumn{3}{|c|}{1000 -grain weight (g) } & \multicolumn{3}{|c|}{ Grain yield $\left(\mathrm{kg} / \mathrm{m}^{2}\right)$} & \multirow[t]{2}{*}{ DSI } \\
\hline & & 2011/12 & $2012 / 13$ & Comb. & 2011/12 & $2012 / 13$ & Comb & $2011 / 12$ & $2012 / 13$ & Comb. & \\
\hline \multirow{4}{*}{$\begin{array}{l}\text { Water } \\
\text { stress } \\
(\mathrm{T})\end{array}$} & $\mathrm{L}$ & $4.27 \mathrm{a}$ & $4.56 \mathrm{a}$ & $4.36 \mathrm{a}$ & $46.9 \mathrm{a}$ & $46.6 \mathrm{a}$ & $46.8 \mathrm{a}$ & $0.51 \mathrm{a}$ & $0.59 \mathrm{a}$ & $0.55 \mathrm{a}$ & -- \\
\hline & $\mathrm{M}$ & $3.71 \mathrm{~b}$ & $4.10 \mathrm{~b}$ & $3.96 \mathrm{~b}$ & $43.6 \mathrm{~b}$ & $42.8 \mathrm{~b}$ & $43.2 \mathrm{~b}$ & $0.46 \mathrm{~b}$ & $0.51 \mathrm{~b}$ & $0.49 \mathrm{~b}$ & 0.16 \\
\hline & $\mathrm{H}$ & $3.44 \mathrm{~b}$ & $3.72 \mathrm{c}$ & $3.58 \mathrm{c}$ & $41.6 \mathrm{c}$ & $42.0 \mathrm{~b}$ & $41.8 \mathrm{c}$ & $0.44 \mathrm{c}$ & $0.37 \mathrm{c}$ & $0.41 \mathrm{c}$ & 0.25 \\
\hline & F.Test & $*$ & $*$ & $* *$ & $* *$ & $* *$ & $* *$ & $* *$ & $* *$ & $* *$ & \\
\hline \multirow{4}{*}{$\begin{array}{l}\text { Cultivars } \\
\text { (V) }\end{array}$} & Sids 12 & $4.86 \mathrm{a}$ & $5.30 \mathrm{a}$ & $5.10 \mathrm{a}$ & $44.4 \mathrm{a}$ & $43.3 \mathrm{~b}$ & $43.8 \mathrm{~b}$ & $0.49 \mathrm{a}$ & $0.57 \mathrm{a}$ & $0.52 \mathrm{a}$ & 0.20 \\
\hline & Misr 1 & $3.38 \mathrm{~b}$ & $3.50 \mathrm{~b}$ & $3.45 \mathrm{~b}$ & $45.7 \mathrm{a}$ & $45.5 \mathrm{a}$ & $45.6 \mathrm{a}$ & $0.47 \mathrm{a}$ & $0.53 \mathrm{a}$ & $0.50 \mathrm{a}$ & 0.42 \\
\hline & Giza 168 & $3.20 \mathrm{~b}$ & $3.56 \mathrm{~b}$ & $3.37 \mathrm{~b}$ & $42.1 \mathrm{~b}$ & $42.6 \mathrm{~b}$ & $42.4 \mathrm{c}$ & $0.43 \mathrm{~b}$ & $0.39 \mathrm{~b}$ & $0.41 \mathrm{~b}$ & 0.13 \\
\hline & F. Test & $* *$ & $* *$ & $* *$ & $* *$ & $* *$ & $* *$ & $* *$ & $* *$ & $* *$ & \\
\hline Interaction & $\mathrm{T} \times \mathrm{V}$ & ns & ns & ns & ns & $*$ & $* *$ & $*$ & $* *$ & $* *$ & \\
\hline
\end{tabular}

*, ** and ns: Significant at 0.05 and 0.01 levels of probability and not significant, respectively.

Means followed a common letter are not significantly differed at 0.05 level.

Significant differences among irrigation treatments were detected for number of spikelets/ spike (Table 3). Subjecting wheat plants to less moisture conditions decreased number of spikelets compared with other treatments but the differences between moderate and high moisture conditions were not significant. Number of spikelets/ spike was maximized in case of Sids 12; 20.1 and 21.9 for both seasons, respectively.

Regarding to number of grains/ spike and number of spikes/ $\mathrm{m}^{2}$, results in Table 3 showed that subjecting wheat plants to high moisture conditions detected the most favorable estimates for both characters. However, the differences between moderate and severe stress conditions were not significant, as both of them were suffered from water stress at heading which is particularly sensitive to water deficit by its direct effect on number of grains/ spike. Large variations among wheat cultivars were detected for the aforementioned two traits. Number of grains/ spike was maximized in case of Sids 1 (81 grains). Number of kernels/ spike and number of spikes/ $\mathrm{m}^{2}$ were decreased significantly by water stress at the different growth stages, and the reduction may attributed to the reduction in photosynthetic efficiency under insufficient water conditions (Hassan, 2005). Similar results were also obtained by Ali \& Akhter (2008). Exposure of wheat plants to drought stress under high temperature significantly decreased number of ears/ plot and grains/ ear (Amin, 2011).

Holding irrigation either at heading and/ or grain filling was associated by significant decrease in spike weight, 1000-grain weight and grain yield (Table 4). This trend was true in the two seasons and the combined. Reduction in spike weight may be due to lower number of grains/ spike and lower 1000-grain

Egypt. J. Agron. 35, No. 2 (2013) 
weight under stress conditions. Previous results showed that exposing wheat plants to drought at grain filling stage caused the highest reduction in 1000-grain weight, due to the reduction in available assimilates for grain filling (Hassan, 2005). Reduction in grain yield may be due to less number of grains/ spike, reduction in number of spikes $/ \mathrm{m}^{2}$ and 1000-grain weight. Significant differences were detected among wheat genotypes. Sids 12 recorded the most desirable value for spikes weight in both seasons and the combined; 4.86, 5.3 and 5.1, respectively. However, Misr 1 wheat cultivar recorded significantly heavier 1000-grain weight and grain yield compared with the other two cultivars, but the differences between Misr 1 and grain were not significant for grain yield. Subjecting wheat cultivars to moderate or severe water stress at any of these stages; seeding to maximum tillering, maximum tillering to flowering or at flowering to maturity decreased plant height, ear number, 1000-grain weight and grain yield (Choudhury \& Kumar, 1980). Reduction in grain yield due to water stress at reproductive development was mainly due to reduction in No. of tillers $/ \mathrm{m}^{2}$, number of grains/ spike and 1000-grain weight (Qadir et al., 1999).

Results in drought susceptibility index between low and high water stress are presented in Table 4. Results showed that genotype which exhibited the highest yield potential under non-stressed condition has failed to produce the same level of yield under high stress. Results showed that exposure wheat plants to high moisture stress resulted in reduction in grain yield by about $25 \%$, where such reduction was about $16 \%$ under moderate water stress (two irrigations). Wheat genotypes exhibited large variation in yield reduction under severe water stress compared with low stress conditions. Misr 1 was the most sensitive to water deficit and recorded the highest DSI value (0.42), followed by Sids $12(20 \%)$ and Giza $168(13 \%)$. The previous results were in accordance with those reported by Drikvand et al. (2012).

\section{Interaction effects}

The significant interaction effects between wheat cultivars and irrigation treatments are presented in Table 5. Heading date was significantly affected by the interaction between wheat cultivars and irrigation treatments. The most favorable value for heading date ( 93.5 days) recorded by Sids 12 wheat cultivar under severe moisture stress. The plant height of Misr 1 was strongly decreased from 114.2 to $98.5 \mathrm{~cm}$ by moving the irrigation level from three irrigations to two irrigations. The most desirable estimates for plant height $(91.5 \mathrm{~cm})$ were associated with high moisture stress in case of Misr 1 wheat cultivar. Number of spikes/ $\mathrm{m}^{2}, 1000$ grain weight and grain yield were significantly affected by the interaction between irrigation treatments and wheat cultivars. Sids 12 surpassed the other cultivars and recorded the most favorable estimates for such traits when it subjected to high moisture conditions. However, the differences between moderate and high moisture stress were not significant for number of spikes $/ \mathrm{m}^{2}$ in case of Giza 168. Holding irrigation at grain filling of Giza 168 wheat cultivar showed in-significant effects on grain yield compared with three irrigations. These results were in genera agreement with those of Sharaan et al. (2000) and Ahmadi et al. (2009). 
TABLE 5. Heading date, plant height, No. of spikes/ $\mathrm{m}^{2}$, 1000-grain grain weight and grain yield influenced by the interaction between water stress and wheat cultivars over two seasons.

\begin{tabular}{|c|c|c|c|c|c|c|}
\hline Cultivars & Water stress & $\begin{array}{c}\text { Heading } \\
\text { date } \\
\text { (day) }\end{array}$ & $\begin{array}{l}\text { Plant } \\
\text { height } \\
(\mathrm{cm})\end{array}$ & $\begin{array}{c}\text { No. } \\
\text { spikes/ } \mathbf{m}^{2}\end{array}$ & $\begin{array}{c}\text { 1000- } \\
\text { grain } \\
\text { weight } \\
\text { (g) }\end{array}$ & $\begin{array}{c}\text { Grain } \\
\text { yield } \\
\left(\mathbf{k g} / \mathbf{m}^{2}\right)\end{array}$ \\
\hline \multirow{3}{*}{ Sids 12} & $\mathrm{~L}$ & $99.8 \mathrm{c}$ & $100.8 \mathrm{~b}$ & $207.6 \mathrm{fg}$ & $48.0 \mathrm{a}$ & $0.59 \mathrm{a}$ \\
\hline & M & $95.2 \mathrm{f}$ & $96.6 \mathrm{de}$ & $196.5 \mathrm{~g}$ & $42.5 \mathrm{c}$ & $0.53 \mathrm{~b}$ \\
\hline & $\mathrm{H}$ & $93.5 \mathrm{~g}$ & $91.5 \mathrm{f}$ & $163.8 \mathrm{~h}$ & $41.1 \mathrm{~cd}$ & $0.47 \mathrm{c}$ \\
\hline \multirow{3}{*}{ Misr 1} & $\mathrm{~L}$ & $105.2 \mathrm{a}$ & $114.2 \mathrm{a}$ & $344.1 \mathrm{a}$ & $47.1 \mathrm{a}$ & $0.62 \mathrm{a}$ \\
\hline & M & $101.5 \mathrm{~b}$ & $98.5 \mathrm{bcd}$ & $314.0 \mathrm{~b}$ & $45.2 \mathrm{~b}$ & $0.53 \mathrm{~b}$ \\
\hline & $\mathrm{H}$ & $99.5 \mathrm{c}$ & $96.0 \mathrm{de}$ & $262.2 \mathrm{c}$ & $44.5 \mathrm{~b}$ & $0.36 \mathrm{e}$ \\
\hline \multirow{3}{*}{ Giza 168} & $\mathrm{~L}$ & $101.7 \mathrm{c}$ & $100.1 \mathrm{bc}$ & $242.7 \mathrm{~d}$ & $45.1 \mathrm{~b}$ & $0.45 \mathrm{~cd}$ \\
\hline & M & $98.5 \mathrm{~d}$ & 97.3 cde & $227.7 \mathrm{e}$ & $42.0 \mathrm{c}$ & $0.41 \mathrm{de}$ \\
\hline & $\mathrm{H}$ & $96.8 \mathrm{e}$ & $94.6 \mathrm{e}$ & $211.9 \mathrm{f}$ & $40.0 \mathrm{~d}$ & $0.39 \mathrm{e}$ \\
\hline
\end{tabular}

Means followed a common letter are not significantly differed at 0.05 level.

$\begin{array}{lll}\text { L: Low water stress } & \text { M: Medium water stress } \quad H: \text { High water stress }\end{array}$

From the aforementioned results it is clear that high moisture conditions (three irrigations) is required to obtain high yield potential from Sids 12 and Misr 1, while, moderate moisture conditions (two irrigations) may be sufficient for Giza 168.

\section{Variance components}

Estimates of variance components, phenotypic (PCV), and genotypic (GCV) coefficients of variability, broad sense heritability and genetic advance are presented in Table 6. Genotypic $\left(\sigma^{2} \mathrm{~g}\right)$ variances were highly significant for all the studied traits, indicating that wheat cultivars differed in their genetic potential. Also the variances due to water stress were significant or highly significant for all the studied traits, reflecting the direct effect of moisture conditions on the expression of such traits. Variance components indicated that the interaction of genotype with moisture treatments was great in magnitude in determining the performance of heading date, plant height, number of spikes $/ \mathrm{m}^{2}$, 1000-grain weight and grain yield. Significant G x T interaction revealed that the genotypes interacted considerably with the moisture changes.

Wheat cultivars showed wide range of variation for all studied traits. The extent of coefficient of variation indicated that high estimates of phenotypic (PCV) and genotypic (GCV) coefficients of variability were exhibited by number of grains/ spike (23.7 and 22.3), number of spikes/ $\mathrm{m}^{2}$ (26.1 and 24.14), spike weight (26.5 and 24.2) and grain yield (33.6 and 32.3\%) for PCV and $\mathrm{GCV}$, respectively. High GCV values for the aforementioned four traits indicated that these traits might be more genotypically controlled and it would be

Egypt. J. Agron. 35, No. 2 (2013) 
possible to achieve further improvement from them. High heritability estimates in broad sense were detected for heading date $(93.8 \%)$, grain yield (92.3), spike length $(91.9 \%)$, number of grains/ spike $(88.8 \%)$, number of spikes/ $\mathrm{m}^{2}(85.5)$ and spike weight (82.9) while, it was moderate for the other traits. Ajmal et al. (2009) found that the magnitude of broad sense heritability were detected by plant height, grains/ spike and grain yield; 0.94, 0.92 and 0.91, respectively. While, it was low for number of spikelets.

TABLE 6. Estimates of variance components, phenotypic (PCV), and genotypic (GCV) coefficients of variability, broad sense heritability and genetic advance for all the studied traits (data over two seasons).

\begin{tabular}{|c|c|c|c|c|c|c|c|c|c|}
\hline Parameters & $\begin{array}{c}\text { Heading } \\
\text { date } \\
(\mathrm{cm})\end{array}$ & $\begin{array}{c}\text { Plant } \\
\text { height } \\
\text { (day) }\end{array}$ & $\begin{array}{c}\text { Spike } \\
\text { length } \\
(\mathrm{cm})\end{array}$ & $\begin{array}{c}\text { No.of } \\
\text { spikelets/ } \\
\text { spike }\end{array}$ & $\begin{array}{c}\text { No.of } \\
\text { grains/ } \\
\text { spike }\end{array}$ & $\begin{array}{c}\text { No.of } \\
\text { spikes/ } \mathbf{m}^{2}\end{array}$ & $\begin{array}{c}\text { Spike } \\
\text { weight } \\
\text { (g) }\end{array}$ & $\begin{array}{c}\text { 1000- } \\
\text { grain } \\
\text { weight } \\
\text { (g) }\end{array}$ & $\begin{array}{c}\text { Grain/ } \\
\text { yield } \\
\left(\mathrm{kg} / \mathrm{m}^{2}\right)\end{array}$ \\
\hline $\begin{array}{l}\text { Mean } \\
\left(X^{-}\right)\end{array}$ & 99.1 & 98.8 & 11.9 & 19.8 & 64.5 & 241.2 & 3.97 & 43.9 & 0.48 \\
\hline$\sigma^{2} \mathrm{~g}$ & $8.63 * *$ & $22.5^{* *}$ & $0.57 * *$ & $1.38 * *$ & $206.6^{* *}$ & $3388.9 * *$ & $0.92 * *$ & $2.45^{* *}$ & $0.024 * *$ \\
\hline$\sigma^{2} \mathrm{gt}$ & $0.06^{*}$ & $8.1 * *$ & $0.02 \mathrm{~ns}$ & $0.09 \mathrm{~ns}$ & $8.28 \mathrm{~ns}$ & $71.9^{* *}$ & $0.065 \mathrm{~ns}$ & $1.35^{* * *}$ & $0.002 * *$ \\
\hline$\sigma^{2} \mathrm{t}$ & $8.08 * *$ & $29.0 * *$ & $0.01 *$ & $0.86^{* *}$ & $15.0 *$ & $641.9^{* *}$ & $0.04 * *$ & $2.23 * *$ & $0.004 * *$ \\
\hline PCV & 3.16 & 5.9 & 6.61 & 6.85 & 23.7 & 26.1 & 26.5 & 4.90 & 33.6 \\
\hline GCV & 2.96 & 4.8 & 6.3 & 5.94 & 22.3 & 24.14 & 24.2 & 3.56 & 32.3 \\
\hline$\left(h^{2} b s\right)$ & 93.8 & 66.2 & 91.9 & 75.0 & 88.8 & 85.5 & 82.9 & 53.4 & 92.3 \\
\hline$(\Delta \mathrm{g})$ & 3.13 & 8.02 & 1.49 & 2.10 & 27.88 & 110.9 & 1.79 & 2.36 & 0.30 \\
\hline$(\Delta \mathrm{g}(\%)$ & 6.1 & 8.1 & 12.5 & 10.6 & 43.2 & 45.9 & 45.3 & 5.4 & 63.0 \\
\hline
\end{tabular}

The expected genetic advance under selection as a percentage of mean found to be high in magnitude for grain yield $(63.0 \%)$, number of spikes/ $\mathrm{m}^{2}(45.9 \%)$, spike weight $(45.3 \%)$, number of grains/ spike (43.0\%). High genetic advance from selection for the previous traits may be due to the large variation among the studied wheat cultivars in respect to such traits. High heritability is not always associated with high genetic gain from selection, but in order to make effective selection, high heritability should be associated with high genetic gain (Dixit et al., 1970). High heritability estimates coupled with high genetic gain from selection were recorded for grain yield, number of grains/ spike, number of spike/ $\mathrm{m}^{2}$ and spike weight, indicating that the selection of these traits should be effective and satisfactory for successful breeding purposes. Selection upon these traits would be directly reflected on further improvement in grain yield. These results were, in general, agree with those reported by Al- Tabbal (2012) and Khan (2013).

\section{Trait associations}

Grain yield is considered the most reliable criteria for selection. It is a complex trait and associated with the other characters. It is therefore, become imperative to 
study degree to which different characters are correlated among themselves as well as grain yield (Usman et al., 2003). The correlations among all pairs of characters are presented in Table 7. Correlation between grain yield and measured traits under irrigation condition was different from drought stress conditions, suggesting that grain yield controlling mechanisms operate differently under these conditions (Ahmadi et al., 2009). The results indicated that, under stress conditions, spike length, number of spikelets/ spike, number of grains/ spike and spike weight were positively correlated with grain yield, whereas these traits were plant height, number of spikes/ $\mathrm{m}^{2}$ and 1000-grain weight in case of high moisture conditions. Grain yield was positively correlated with spike yield under drought and irrigation conditions (Telebi et al., 2010).

TABLE 7. Phenotypic simple correlation coefficients among the studied traits under three water stress conditions averaged over three wheat cultivars and two years.

\begin{tabular}{|c|c|c|c|c|c|c|c|c|c|}
\hline Characters & $\begin{array}{l}\text { Water } \\
\text { stress }\end{array}$ & $\begin{array}{c}\text { Plant } \\
\text { height }\end{array}$ & $\begin{array}{l}\text { Spike } \\
\text { length }\end{array}$ & $\mid \begin{array}{c}\text { Spikelets/ } \\
\text { spike }\end{array}$ & $\begin{array}{c}\text { Grains / } \\
\text { spike }\end{array}$ & $\mid \begin{array}{c}\text { Spikelets/ } \\
\mathbf{m}^{\mathbf{2}}\end{array}$ & $\begin{array}{c}\text { Spike } \\
\text { weight }\end{array}$ & $\begin{array}{c}\text { 1000- } \\
\text { grain } \\
\text { weight }\end{array}$ & $\begin{array}{c}\text { Grain / } \\
\text { yield }\end{array}$ \\
\hline \multirow{3}{*}{$\begin{array}{l}\text { Heading } \\
\text { date }\end{array}$} & $\mathrm{L}$ & $0.91 * *$ & -0.66 & $-0.76^{*}$ & $-0.75^{*}$ & $0.99 * *$ & $-0.71 *$ & 0.06 & 0.36 \\
\hline & M & $0.70^{*}$ & $-0.95^{* *}$ & $-0.81 * *$ & $-0.90 * *$ & $0.94^{* *}$ & $-0.78^{*}$ & $0.77 *$ & -0.03 \\
\hline & $\mathrm{H}$ & $0.92 * *$ & $-0.98 * *$ & $-0.93 * *$ & $-0.83 * *$ & $0.90 * *$ & $-0.77 *$ & $0.67 *$ & $-0.92 * *$ \\
\hline \multirow{3}{*}{$\begin{array}{l}\text { Plant } \\
\text { height }\end{array}$} & $\mathrm{L}$ & & -0.56 & -0.55 & -0.53 & $0.93 * *$ & -0.41 & 0.34 & $0.68^{*}$ \\
\hline & M & & $-0.72 *$ & -0.49 & -0.49 & $0.77 *$ & -0.56 & 0.62 & 0.18 \\
\hline & $\mathrm{H}$ & & $-0.78 * *$ & $-0.76^{*}$ & $-0.83 * *$ & $0.87 * *$ & $-0.77 *$ & 0.51 & $-0.90 *$ \\
\hline \multirow{3}{*}{$\begin{array}{l}\text { Spike } \\
\text { length }\end{array}$} & $\mathrm{L}$ & & & $0.83^{* *}$ & $0.92 * *$ & $-0.74 *$ & $0.74 *$ & 0.36 & -0.08 \\
\hline & M & & & $0.86^{* *}$ & $0.91 * *$ & $-0.87 * *$ & $0.80 *$ & -0.66 & 0.15 \\
\hline & $\mathrm{H}$ & & & $0.94 * *$ & $0.75^{*}$ & $-0.98 * *$ & $0.73^{*}$ & $-0.68 *$ & $0.88^{* *}$ \\
\hline \multirow{3}{*}{$\begin{array}{l}\text { Spikelets/ } \\
\text { spike }\end{array}$} & $\mathrm{L}$ & & & & $0.96^{* *}$ & $-0.78^{*}$ & $0.90 * *$ & 0.49 & 0.17 \\
\hline & M & & & & $0.79 *$ & $-0.77 *$ & 0.62 & -0.64 & 0.06 \\
\hline & $\mathrm{H}$ & & & & 0.66 & $-0.95^{* *}$ & 0.63 & $-0.75 *$ & $0.78^{*}$ \\
\hline \multirow{3}{*}{$\begin{array}{l}\text { Grains/ } \\
\text { spike }\end{array}$} & $\mathrm{L}$ & & & & & $-0.78^{*}$ & $0.93 * *$ & 0.49 & 0.15 \\
\hline & M & & & & & $-0.71 *$ & $0.89 * *$ & -0.43 & 0.45 \\
\hline & $\mathrm{H}$ & & & & & $-0.79 *$ & $0.92 * *$ & -0.19 & 0.81 ** \\
\hline \multirow{3}{*}{$\begin{array}{l}\text { Spikelets/ } \\
\mathrm{m}^{2}\end{array}$} & $\mathrm{~L}$ & & & & & & $-0.70^{*}$ & 0.05 & 0.40 \\
\hline & M & & & & & & -0.59 & $0.91 * *$ & 0.25 \\
\hline & $\mathrm{H}$ & & & & & & $-0.73^{*}$ & $0.71^{*}$ & $-0.89 * *$ \\
\hline \multirow{3}{*}{$\begin{array}{l}\text { Spike } \\
\text { weight }\end{array}$} & $\mathrm{L}$ & & & & & & & 0.49 & 0.31 \\
\hline & $\mathrm{M}$ & & & & & & & -0.26 & 0.52 \\
\hline & $\mathrm{H}$ & & & & & & & -0.07 & 0.82 ** \\
\hline $1000-$ & $\mathrm{L}$ & & & & & & & & $0.82 * *$ \\
\hline grain & M & & & & & & & & 0.57 \\
\hline weight & $\mathrm{H}$ & & & & & & & & -0.53 \\
\hline
\end{tabular}

Egypt. J. Agron. 35, No. 2 (2013) 
1000-grain was positively correlated with each of heading date and number of spikelets $/ \mathrm{m}^{2}$ under moderate and high moisture stress, while it was negatively correlated with spike length under high water stress. Spike weight was positively correlated with each of number of grains/ spike and spike length under all water moisture and negatively with plant height under severe water stress. Previous results showed that both spike weight and kernel weight per spike were the most related to grain yield under stress and non-stress conditions (Ismail et al., 2003).

Strong positive association between plant height and each of heading date and number of spikes $/ \mathrm{m}^{2}$ under all moisture conditions and with high grain yield under high moisture conditions. These results confirmed the previous results where Misr1 was the tallest cultivar and gave the highest values of heading date, spikes/ $\mathrm{m}^{2}$ and grain yield (under high moisture conditions). While, the association between plant height and grain yield was negative under drought stress (-0.90). Such result confirms the strong reduction of grain yield in case of Misr1 from 0.62 to $0.36 \mathrm{~kg} / \mathrm{m}^{2}$ with decreasing number of irrigations from three to one irrigation. Also, plant height was negatively correlated with spike length under all moisture treatments. These results are logic as Sids 12 wheat cultivars recorded the longest spike but it in the same time gave the shortest plants under all moisture regimes. Strong negative association were detected between plant height and each of spikelets/ spike, grains/ spike and spike weight, this may be interpreted that the most favorable values from such traits were recorded for Sids 12 which detected the lowest estimates of plant height.

Heading date, addition to its relation with plant height, was positively correlated with spikelets/ $\mathrm{m}^{2}$ and 1000-grain weight under all moisture condition, and negatively associated with grain yield under drought. This may be confirmed the aforementioned results where Misr 1 which gave the highest estimates for heading date and grain yield under high moisture conditions was strongly decreased in its grain yield when it exposure to drought stress.

Spike length, in addition to its relation with grain yield showed strong positive correlation with spikelets/ spike, grains/ spike and spike weight under all water treatments, while it showed negative association with 1000-grain weight under high water stress $(-0.68)$.

Number of grains/ spike, beside its relations with spike length and number of spikelets/ spike, showed strong positive correlation with spike weight under all water treatments. However it negatively correlated with spikes $/ \mathrm{m}^{2}$, this may be true that great numbers of spikes per unit area may be reflected on fewer number of grains/ spike. Previous results showed that grain yield was positively correlated with each of plant height, spike length, grains/ spike and 1000-grain weight under water stress condition and with tillers/ plant, spike length, grains/ spike and 1000-grain weight plant under irrigated conditions condition (Subhani \& Chowdhry, 2000). Similar results were also obtained by Eman et al. (2012). 
From the previous results, it was clear that, the genotype which exhibited the highest yield potential under non-stressed condition has failed to produce the same level of yield under drought stress. Wheat genotypes exhibited large variation in yield reduction under severe water stress compared with low stress conditions. Misr 1 was the most sensitive to water deficit and recorded the highest DSI value (0.42), followed by Sids 12 and Giza 168, suggesting that Giza 168 wheat cultivar was the most desirable wheat cultivar regarding to drought tolerance.

\section{References}

Ahmadi, A., Jodi, M., Tavakoli, A. and Ranjbar, M. (2009) Investigation of yield and its related morphological traits responses in wheat genotypes under drought stress and irrigation conditions. Journal of Science and Technology of Agriculture and Natural Resourses, Water and Soil Science, 12 (46), 155-165.

Ajmal, S.U., Zakir, N. and Mujahid, M.Y. (2009) Estimation of gene parameters and characters association in wheat. J. Agric. Biol. Sci. 1 (1), 15-18.

Al-Tabbal, J.A. (2012) Heritability studies of yield and yield associated traits in wheat genotypes. Journal of Agricultural Science, 4 (4), 11-22.

Ali, D., Monnerux, P.H. and Araus (1990) Breeding durum wheat for drought tolerance. Analytical synthetical approaches and their connection: In : "Wheat Breeding and Future Approaches". Bulgarian Agricultural Academy, Bulgaria, pp. 224-240.

Ali, Y. and Akhter, J. (2008) Drought tolerance in wheat genotypes. International Journal of Biology and Biotechnology, 5, 65-69.

Amin, A.M. (2011) The effect of water and heat stress on wheat. Agricultura Tropica et Subtropica , 44 (1), 44-47.

Bartelett, M.S. (1937) Properties of sufficiency and statistical tests. Proc. Roy. Soc. London, Series A 160, 268-282.

Blum, A., Johnson, J.W., Ramseux, E.L. and. Tollner, E.W. (1991) The effect of drying top soil and a possible non-hydraulic root signal on wheat growth and yield. $J$. Exp. Botany , 42 (243), 1225-1231.

Burton, G.W. (1952) Quantitative inheritance in grasses. Proc. $3^{\text {rd }}$ Int. Grassid Congr. 1, 227-283.

Choudhury, P.N. and Kumar, V. (1980) The sensitivity of growth and yield of dwarf wheat to water stress at three growth stages. Irrigation Science, 1, 223-231.

Chowdhry, M.A., Rasool, I., Khaliq, I., Mahmood, T. and Gilani, M.M. (1999) Genetic of some metric traits in spring wheat under normal and drought environment. Rachis Newsletter, 18 (1), 34-39.

Dixit, P. K., Saxena, P.D. and Bhatia, A. (1970) Estimation of genotypic variability of some quantitative characters in ground nut. Indian Journal of Agric. Sci. 40, 197-201.

Egypt. J. Agron. 35, No. 2 (2013) 
Drikvand, R., Dossty, B. and Hosseipour, T. (2012) Response of rainfed wheat genotypes to drought stress using drought indices. Journal of Agricultural Science, $\mathbf{4}$ (7), 126-131.

Eman, Y., Rangbar, A.M. and Bahrani, M.J. (2012) Evaluation of yield and yield components in wheat genotypes under post anthesis drought stress. Journal of Science and Technology of Agriculture and Natural Resources, 11 (1), 317-328.

Gomez, K.A. and Gomez, A.A. (1984) "Statistical Procedures for Agricultural Research". John Wiley\& Sons, New Yourk. U.S.A.

Hassan, M.A. (2005) Evaluation of two wheat varieties under different moisture stress and nitrogen fertilization. Proc. $4^{\text {th }}$ Plant Breed. Conf. 9 (1), 49-64.

Ismail, E.A., Emad El-Din, H.M. and Rashad, M.H. (2003) Influence of drought stress on the variation and correlation of vegetative, chemical and yield attributes in durum wheat. Proc. $3^{\text {rd }}$ Plant Breed. Conf. 7 (1), 621-641.

Johnson, H.F., Robinson, H.F. and Comstock, R.E. (1955) Estimates of genetic and environmental variability in soybean. Agron. J. 47, 314-318.

Khan, A.G., Azam, F., Ali, A., Tariq, M. and Amin, M. (2005) Inter -relationship and path coefficient analysis for biometric traits in drought tolerant wheat (Triticum aestivum L.) . Asian Journal of Plant Sciences, 4 (5), 540-543.

Khan, S.A. (2013) genetic variability and heritability estimates in F2 wheat genotypes. International Journal of Agriculture and Crop Sciences, 5 (9), 983-986.

Qadir, G., Saeed, M. and Cheema, M.A. (1999) Effect of water stress on growth and performance of four wheat cultivars. Pakistan Journal of Biological Sciences, 2 (1), 236-239.

Sharaan, A.N., Abd El-Samie, F.S. and Abd El-Gawad, I.A. (2000) Response of wheat varieties (Triticum aestivum L.) to some environmental influences. II: Effect of planting date and drought at different plant stages on yield and its components. Proc. $9^{\text {th }}$ Conf. Agron. 7 (1), 1-15.

Sharma, S.N., Sani, R.S. and Sharma, R.K. (2002) Gene system governing yield per spike in macaroni wheat. Wheat Infor. Service, 94, 14-18.

Soil Survey Staff (2010) "Key of Soil Taxonomy": $10^{\text {th }}$ ed. USDA-NRCS. Gov. Print. Office, Washington, D.C.

Singh, R.K. and Chaudhary, B.D. (1985) "Biometrical Methods in Quantitative Genetic Analysis". Kalyani Publishers, New Delhi.

Steel, R.G.D. and Torrie, J.H. (1980) "Principals and Procedures of Statistics, a Biometrical Approoach". $2^{\text {nd }}$ ed. MC. Graw-Hill Co., New York.

Subhani, G.M. and Chowdhry, M.A. (2000) Correlation and path coefficient analysis in bread wheat cultivar under drought stress and normal conditions. Pakistan Journal of Biological Sciencs, 3 (1), 72-77. 
Talebi, R., Fayyaz, F. and Naji, A.M. (2010) Genetic variation and interrelationship of agronomic characteristics in durum wheat under two constructing water regimes. Barazilian Archeives of Biology and Technology , 53 (4), 785-791.

Usman, M., Chowdhry, M.A., Khaliq, I. and Ahmad, R. (2003) Morphological response of various genotype to drought conditions. Asian Journal of Plant Sciences, 2 (4), 292-394.

Zhang, H. and Oweis, T. (1999) Water yield relations and optimal irrigation scheduling of wheat in the Mediterranean region. Agricultural Water Management, 38 (3), 195-211.

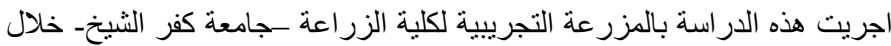

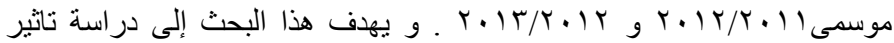

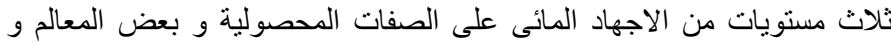

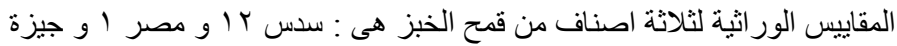

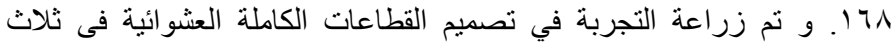
مكررات لكل مستوى من مستويات الاجهاد المائى. و تم دراسة الصنة الصفات الاتية،

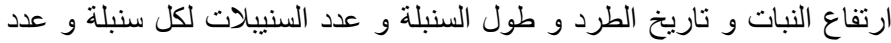

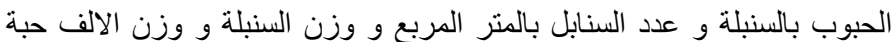

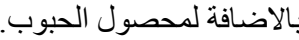

ادى الاجهاد المائى الحاد (رية واحدة) و المنوسط (ريتين) إلى انخفاض

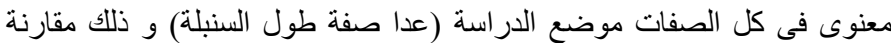

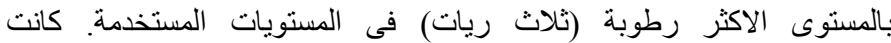
الاختلافات بين المستوى الاعلى و المتوسط من الاجهاد غير معنوى لصفات فلات عدد

Egypt. J. Agron. 35, No. 2 (2013) 
PERFORMANCE AND GENOTYPIC VARIABILITY OF THREE BREAD ... 225

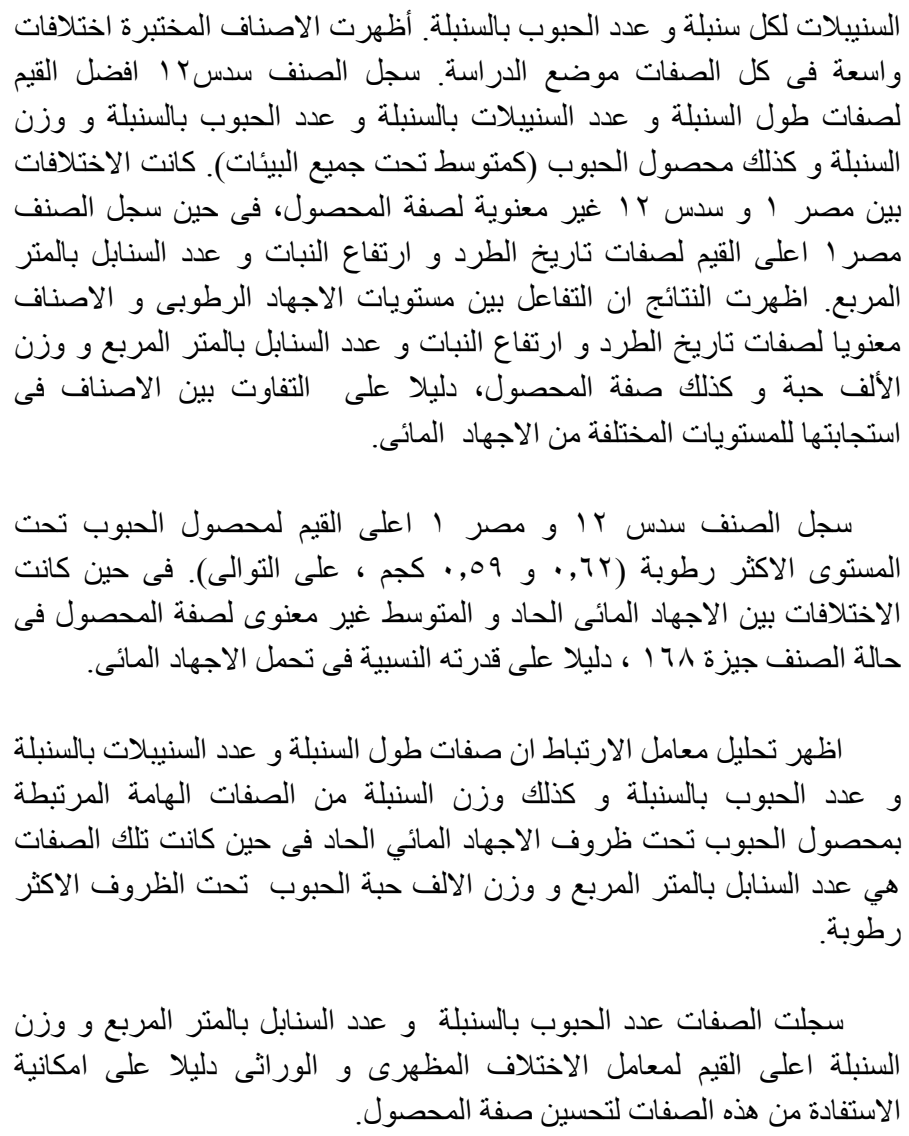

